\title{
NEUTRALIDAD IDEOLÓGICA DEL CARGO EJECUTIVO O PARLAMENTARIO QUE REINGRESA A LA CARRERA JUDICIAL: PERSPECTIVA ÍTALO-ESPAÑOLA ${ }^{\top}$
}

\author{
FELIO JOSÉ BAUZÁ MARTORELL \\ Universidad de las Islas Baleares
}

\section{Resumen}

La ocupación de puestos de responsabilidad política por parte de jueces y magistrados plantea el problema de si en el momento del reingreso a la carrera judicial su neutralidad ideológica — como proyección de la independencia e imparcialidad— se halla comprometida.

En este artículo se analiza la idea de que en derecho europeo las constituciones italiana y española tienen del juez, en tanto que detentador de un poder del Estado, y las connotaciones que tiene la cualidad de Juez, incluso al margen de la función estrictamente judicial.

Fruto del estudio del estatuto jurídico del juez, se proponen reformas de lege ferenda para asegurar al máximo la confianza social en la justicia.

1 Artículo redactado con ocasión de la estancia en la Scuola di Specializzazione in Studi sull'Amministrazione Pubblica (Università di Bologna), bajo la dirección del profesor Dr. Luciano Vandelli. 


\section{Palabras clave}

Neutralidad ideológica; independencia judicial; imparcialidad; política.

\section{Abstract}

The occupation of positions of political responsibility on the part of Judges and Magistrates raises the problem of whether at the time of re-entry to the judicial career their ideological neutrality — as a projection of independence and impartiality — is compromised.

This article analyzes the idea that in European law the Italian and Spanish Constitutions have the Judge, as holder of a power of the State, and the connotations that have the quality of Judge, even outside the strictly judicial function.

As a result of the study of the juridical statute of the Judge, lege ferenda reforms are proposed to ensure maximum social trust in the Justice.

\section{Keywords}

Ideological neutrality; Judicial independence; Impartiality; Politics. 


\section{SUMARIO}

I. PLANTEAMIENTO. II. LA IDEA CONSTITUCIONAL DE JUEZ: 1. Independencia de la función judicial. 2. Neutralidad ideológica del juez. 3. Confianza social en el juez. 4. Libertad de expresión del juez. III. INSUFICIENCIAS DEL DERECHO POSITIVO: 1. Ordenamiento italiano: 1.1. Códigos de conducta. 1.2. Régimen de incompatibilidades. 1.3. Inadecuación de nombramientos. 2. Ordenamiento español: 2.1. Jueces y magistrados del Poder Judicial. 2.2. Magistrados del Tribunal Constitucional. IV. LA DIFÍCIL INDEPENDENCIA DEL JUEZ QUE HA SIDO ALTO CARGO O PARLAMENTARIO. V. RECOMENDACIONES DE LEGE FERENDA: HACIA UN CÓDIGO DE CONDUCTA DE JUECES Y MAGISTRADOS.

\section{PLANTEAMIENTO}

El cese de la Sra. Anna Finocchiaro como ministra del gobierno italiano ha planteado una cuestión nada baladí, cual es la neutralidad ideológica de la carrera judicial ${ }^{2}$. Con ocasión de su cese, la Sra. Finocchiaro ha reconocido su dificultad - después de treinta y un ańos ininterrumpidos de actividad política- de reingresar en la carrera judicial y ejercer su función con neutralidad e independencia.

Este debate, que en Italia se ha originado en la opinión pública, no es distinto al que puede (y debe) plantearse en España, donde jueces y magistrados ocupan puestos de responsabilidad política (los ministros del Interior de los dos últimos gobiernos de la nación son magistrados), o bien desempeñan actividad parlamentaria en las Cortes Generales o en asambleas autonómicas.

Lo cierto es que los jueces no se habían dejado seducir por la política de manera tan significativa hasta fechas recientes. En los primeros cuarenta años de Constitución española lo más cerca que había estado la política de la judicatura era en los nombramientos de los vocales del Consejo General del Poder Judicial y el asociacionismo de los miembros de la carrera judicial y fiscal, asuntos que han generado abundante literatura jurídica.

2 La Sra. Finocchiaro ejerció de procuradora sustituta en Catania (Sicilia) hasta 1987, fecha en la que inicia una dilatada carrera política como consejera de la comuna de Catania (1988-1995), diputada por la circunscripción de Catania en la Cámara de Diputados (1996-2006), senadora (2006-2016), ministra para la Igualdad de Oportunidades en el Gobierno Prodi (2001) y ministra de Relaciones con el Parlamento en el Gobierno Gentiloni (2016-2018). 
Un caso llamativo fuera de Europa es el del juez federal Sergio Moro en Brasil, que después de instruir la Operación Autolavado (Operaçao Lava Jato) — por la que se condenó al expresidente Lula da Silva a privación de libertad- se convirtió en ministro de Justicia y Seguridad Pública del Gobierno Bolsonaro.

El movimiento Manos limpias en Italia (mani pulite), de lucha contra la corrupción, fue protagonizado esencialmente por magistrados y fiscales ${ }^{3}$. Entre estos últimos algunos siguen en la magistratura, mientras que otros participan activamente en la vida política: el caso más conocido es el de Antonio Di Pietro, antiguo fiscal general que — después de la investigación de Manos limpias- inició una carrera política como cabeza del partido Italia de los Valores que le llevó a ser elegido senador, europarlamentario y diputado, así como a dirigir los ministerios de Obras Públicas e Infraestructuras en los gabinetes de Romano Prodi (19961998 y 2006-2008). Otro caso es el de Luigi de Magistris, fiscal en Nápoles y fiscal general en Catanzaro, dedicado fundamentalmente a asuntos de corrupción. En 2009 obtuvo acta de eurodiputado por el partido Italia de los Valores, y desde 2011 es alcalde de Nápoles.

En España el caso más parecido es el de Baltasar Garzón, otrora Magistrado de la Audiencia Nacional — como tal, encargado de casos de corrupción- con un paréntesis nada menos que como secretario de Estado en Interior (delegado del Plan Nacional contra las Drogas) y a día de hoy, una vez perdida la condición de juez, militante del Partido Actúa ${ }^{4}$. El entonces azote de la corrupción en España y juez estrella fue número dos en las listas del PSOE a las elecciones generales de 1993 detrás de Felipe González, con la intención presumiblemente de ser nombrado ministro del Interior. Después de un año de ser alto cargo en el Ministerio, dimitió para reincorporarse a la Audiencia Nacional e instruyó la causa contra la cúpula del Ministerio del Interior: el ministro Barrionuevo y el secretario de Estado de Seguridad Vera ingresaron en prisión, y —en caso de que se hubiera confirmado que Mr. X era Felipe González o que la abreviatura Pte. significaba Presidente y no pendiente- hasta el entonces presidente del Gobierno podía haber corrido la misma suertes.

La implicación política de quien ejerce funciones ejecutivas o parlamentarias (intervenciones en mítines, campañas electorales...) supone una toma de partido y de opción ideológica que por razones obvias compromete la independencia y neutralidad con la que un juzgador debe ejercer su función judicial, que no puede tener otra adscripción que la Constitución y el resto del ordenamiento jurídico.

3 En Italia, jueces y fiscales pueden alternar sus funciones, mientras que en España se rigen por un estatuto distinto.

4 El Sr. Garzón fue expulsado de la carrera judicial por Sentencia del Tribunal Supremo de 9 de febrero de 2012 como consecuencia de las escuchas ilegales ordenadas a letrados del caso Gürtel.

5 Sobre la forma de instruir de Baltasar Garzón, es cita indispensable S. Muñoz Machado (2010), Riofrío. La Justicia del señor Juez. Barcelona: Edhasa, 256 págs. 
El derecho positivo, tanto en Italia como en España ${ }^{6}$, contempla la incompatibilidad de la función judicial con cualquier cargo de elección popular o designación política, si bien este impedimento se centra a un momento temporal de simultaneidad.

En este sentido el ordenamiento se limita a prohibir que un juez o magistrado desempeñe - mientras ejerce como tal en servicio activo- al mismo tiempo un cargo de responsabilidad política en el poder ejecutivo o legislativo, pero nada dice respecto a cómo queda comprometida su neutralidad ideológica cuando - después de haber pasado a una situación de excedencia o de servicios especiales - reingresa a la carrera judicial, que es el supuesto que vamos a analizar en las páginas que siguen, tanto en el derecho positivo italiano como en el español, analizando si existe alguna laguna que colmar y, en su caso, formulando las recomendaciones de lege ferenda que resulten pertinentes.

Ya advertimos desde un primer momento que, sin lugar a dudas, el juez tiene su ideología, como asimismo no se le puede negar su libertad de expresión. No obstante, ambos derechos fundamentales tienen sus límites —específicos en el juez- allí donde puedan comprometer su independencia y neutralidad. En este sentido, el juez podrá opinar de política; pero en público —en un contexto de casi absoluta ideologización de la vida social— la expresión pública de adhesiones políticas o de críticas exacerbadas va a mermar la confianza social en el juez, que finalmente desencadenará invariablemente una lesión a su independencia. Entre otras cosas, el ordenamiento constitucional pretende un juez ideológicamente aséptico, con nula carga política en sus manifestaciones.

Por último debemos distinguir los cargos públicos con especial carga política (ministro o parlamentario) de aquellos con un perfil más técnico (subsecretarios, secretarios generales técnicos y directores generales), en los que la neutralidad ideológica no tiene por qué haber quedado lesionada.

\section{LA IDEA CONSTITUCIONAL DE JUEZ}

La judicatura cumple una función absolutamente clave en un Estado de derecho. Solo un estamento judicial políticamente independiente puede garantizar la sumisión del poder a derecho, sin que pueda mermarse la confianza de los ciudadanos en los servidores públicos encargados de impartir justicia ${ }^{7}$.

6 Centramos nuestra atención en estos dos ordenamientos, si bien no puede negarse que la independencia judicial es un elemento clave de la separación de poderes que se consagra en docenas de cartas constitucionales y tratados internacionales. Véase, en este sentido, D. Rojas Betancourt (2017), La independencia judicial: institución y derecho, Barranquilla, págs. 178 y ss.

7 Para Ferrajoli, la jurisdicción cumple una función netamente garantista en la separación de poderes, orientada a la determinación de la verdad procesal de hecho y en derecho. 
De hecho, la Constitución italiana — a partir de la premisa general de que «los empleados públicos están al servicio exclusivo de la Nación» (art. 98)— dispone que los jueces solo estarán sometidos a la ley (art. 101), que la Magistratura constituye un orden autónomo e independiente de cualquier otro poder (art. 104), y que los nombramientos de magistrados se harán por oposición (art. 106) ${ }^{8}$.

Por su parte, la Constitución espańola entiende que la justicia emana del pueblo y se administra en nombre del Rey por jueces y magistrados integrantes del poder judicial, independientes, inamovibles, responsables y sometidos únicamente al imperio de la ley (art. 117.1) y que los jueces y magistrados, así como los fiscales, mientras se hallen en activo, no podrán desempeñar otros cargos públicos, ni pertenecer a partidos políticos o sindicatos (art. 127.1).

En la distinción entre los poderes ejecutivo y judicial, debemos aceptar que este último se erige como elemento de revisión del primero y en definitiva de mayor confianza de cara al principio de legalidad. No es que la Administración no esté sujeta a la legalidad, sino que en última instancia, quien decidirá si efectivamente la actuación administrativa fue acorde o no con el ordenamiento jurídico será el juez. No de otra manera se entiende la expresión «siempre nos quedarán jueces en Berlín» (Es gibt noch Richter in Berlin), que explica Soriano García ${ }^{9}$ y que da muestra de la vital importancia de que se mantenga la credibilidad en el poder judicial: ante cualquier acto arbitrario del poder ejecutivo, siempre queda la esperanza en los jueces, garantes de la legalidad y por ende de la justicia ${ }^{10}$. Lo contrario, la desconfianza ciudadana trasciende el desprestigio de la función judicial para dinamitar por completo el Estado de derecho y la democracia ${ }^{11}$.

L. Ferrajoli (2016), Principia iuris. Teoría del derecho y de la democracia. Madrid: Trotta. En el mismo sentido, P. Andrés Ibáńez (2005), Tercero en discordia. Jurisdicción y Juez del Estado constitucional, Madrid, pág. 140.

D. Bifulco (2008), Il giudice è soggetto soltanto al diritto: contributo allo studio dell'articolo 101, comma 2 della Costituzione italiana, Napoli: Jovene.

9 De acuerdo con el relato de Françoise Andrieux, Federico II de Prusia exige a un molinero que le venda su molino porque le tapa la vista desde su palacio. Ante la negativa de este último, el emperador le recrimina que podría confiscárselo sin pagarlo, a lo que el molinero le contesta «siempre nos quedarán jueces en Berlín». J. E. Soriano García (2012), El poder, la Administración y los jueces (A propósito de los nombramientos por el Consejo General del Poder Judicial), Madrid: Iustel, pág. 94.

10 E. Arnaldo Alcubilla (2018), Urnas, legisladores y togas, Madrid: Universidad Rey Juan Carlos, pág. 380.

11 S. Muñoz Machado (2011), «La independencia judicial y el problema de la relación de la justicia con los demás poderes del Estado", Actualidad y perspectivas del derecho público a fines del siglo XX: homenaje al profesor Garrido Falla, vol. 1, págs. 261-278. Véase del mismo autor, (2011), "La posición de los jueces frente a la legalidad, la inseguridad jurídica y otros agujeros negros del Estado de Derecho", Tratado de Derecho Administrativo y Derecho Público General, Madrid: Iustel. 
Desde la perspectiva constitucional debemos preguntarnos qué clase de juez diseñan las constituciones italiana y española. En el modelo americano el juez tiene una carga política indudable y de hecho los jueces son relevados con ocasión de los mandatos presidenciales ${ }^{12}$. En cambio, en Europa la independencia judicial, anclada en la inamovilidad, constituye una característica que no se puede relativizar ${ }^{13}$.

La Constitución pretende un modelo de juez con una independencia sin fisuras, al margen de actividades no digamos directamente políticas, sino que — sean del signo que sean- puedan incorporar cualquier factor que comprometa su independencia. En consecuencia, los derechos que el juez tiene como ciudadano (libertad ideológica y muy especialmente libertad de expresión) se interpretarán en función de cómo pueden afectar a su independencia, porque el juez, o es independiente o no es juez.

Un dato que no puede pasar desapercibido es el concepto o la idea que tiene la Constitución del juez. En efecto, esta expresión aparece en el voto particular del magistrado Excmo. Sr. Lucas Murillo de la Cueva a la Sentencia de la Sala Tercera, de lo Contencioso-administrativo del Tribunal Supremo de 20 de noviembre de 2009 (rec. 559/2008). La sentencia, aprobada por mayoría, confirma el archivo de las actuaciones de la comisión disciplinaria del Consejo General del Poder Judicial relativas al escrito de queja que una jueza dirige al fiscal jefe de la Comunidad Valenciana, en la que manifestaba haber soportado persecución del aparato propagandístico del Gobierno como consecuencia del planteamiento de una cuestión de constitucionalidad sobre la ley que autoriza matrimonios entre personas del mismo sexo.

En su FD séptimo la sentencia entiende que la conducta de la jueza no integra el tipo del art. 418.3 LOPJ («dirigir a los poderes, autoridades o funcionarios públicos o corporaciones oficiales felicitaciones o censuras por sus actos, invocando la condición de juez, o sirviéndose de esta condición»).

En cambio el Magistrado discrepante no comparte el fallo de la sentencia, porque no tiene en cuenta la idea constitucional del juez en tanto confirma que es jurídicamente válido y no genera ninguna responsabilidad manifestarse en el debate público del modo que se ha visto. Para este magistrado:

No contribuye a fomentar la confianza de los ciudadanos en el Poder Judicial que quienes lo ejercen se enzarcen en intercambios de descalificaciones con autoridades o con miembros del Ministerio Fiscal. Tampoco parece corresponderse con la idea de juez que resulta de la Constitución y recoge la Ley Orgánica del Poder

12 Los jueces federales son nombrados por el Presidente de los Estados Unidos con veto del Senado, y los jueces estatales lo son por elección política.

13 Sobre la distinción entre ambos ordenamientos, véase M. Taruffo (2009), «La cultura de la imparcialidad en los países del "Common law" y del derecho continental». En: C. Gómez Martínez (dir.) (2009), La imparcialidad judicial, Madrid: Consejo General del Poder Judicial, págs. 95-120. 
Judicial ese tipo de conductas, cualquiera que sea el contexto en que se produzcan, porque del juez se espera su independencia, su imparcialidad, su estricta sumisión a la Ley y su responsabilidad en el ejercicio de la potestad de juzgar y hacer ejecutar lo juzgado en tutela de los derechos e intereses de todos. Y, también, la prudencia, la serenidad y el respeto al propio oficio necesarios para cumplir con esos cometidos esenciales, todos los cuales se resienten cuando entabla actuaciones como las descritas.

En esta misma línea, el Tribunal Supremo, Sala Tercera, de lo Contencioso-administrativo, en Sentencia de 14 de julio de 1999 (rec. 617/1998), destaca que, si la meta prioritaria de nuestro texto constitucional es establecer un orden democrático de convivencia, según resulta de su preámbulo y art. 1 , habrá de aceptarse que a quienes les sea exigible de manera especial un deber de lealtad constitucional les corresponderá, como parte integrante del mismo, la obligación de abstenerse de realizar conductas que puedan hacer quebrar esa confianza social.

Por consiguiente, no puede negarse que la Constitución diseña un concepto de juez, alejado de cualquier condicionamiento en su toma de decisión, ya sea externo (otros poderes del Estado), pero también interno (su propia ideología, prejuicios, relaciones personales...), hasta el punto de que tan importante como la existencia de esos condicionantes será su apariencia. En este sentido, solo con que parezca que existen elementos comprometedores de su independencia — aunque realmente no existan — se producirá una lesión en el funcionamiento de la justicia.

\section{INDEPENDENCIA DE LA FUNCIÓN JUDICIAL}

Lejos de ser un asunto menor o meramente dogmático, la independencia judicial constituye un pilar fundamental del Estado de derecho, que goza de una doble vertiente ${ }^{14}$ : por un lado, objetivamente la independencia judicial se refiere a la separación de poderes, a la garantía de que no existe injerencia del legislativo y muy especialmente del ejecutivo en el poder judicial ${ }^{15}$; por otro y en su vertien-

14 O. Bachoff (1985), Jueces y Constitución, Madrid: Cuadernos Civitas, págs. 14 y ss.

15 Para Muńoz Machado la garantía de primera de la independencia judicial radica en la exclusividad, en la reserva de la función al cuerpo de los jueces, en la eliminación de cualquier residuo de poder jurisdiccional en manos de los otros dos poderes. S. Muñoz Machado (1989), La reserva de jurisdicción, Madrid: La Ley, pág. 13. El autor explica la formación del principio de independencia (págs. 11 y ss), tanto en derecho comparado (art. 1 del título III, capítulo V de la Constitución francesa de 1791, art. 202 de la Constitución del año III, art. 13 de la Ley 16-24 de agosto de 1790, o los ensayos de Alexander Hamilon en The Federalist), así como en derecho histórico español. En este último caso se refiere al discurso preliminar de Agustín de Argüelles a la Constitución de Cádiz cuando afirma que «se separan de tal modo las funciones del juez de cualquier otro acto de la autoridad soberana, que nunca podrán ni las Cortes ni el Rey ejercerlas bajo ningún pretexto». 
te subjetiva, la independencia de la función judicial obliga a que el juez se halle sometido exclusivamente al imperio de la ley, a la Constitución y al resto del ordenamiento jurídico.

Este aspecto personal de la función judicial constituye un requisito esencial, por cuanto - sin independencia en su actuación - el juez no es tal, sino otra cosa bien distinta; la independencia afecta así al fundamento de la propia función jurisdiccional, decisoria, del derecho entre partes, garantía jurídica de la imparcialidad exigible al juez ${ }^{16}$.

Adicionalmente la independencia del juez resulta incompatible con matices o gradaciones, debiendo ser plena y sin fisuras ${ }^{17}$.

La independencia personal y subjetiva del juez debe ser objetivamente (no es un juego de palabras) contrastable, al fin de negar el realismo individualista que permite anticipar el fallo de una sentencia en función del juez que vaya a dictarla ${ }^{18}$.

En consecuencia, la toma decisión del juez, la ponderación y valoración del caso, debe hacerse al margen de cualquier presión, ya sea social, mediática o incluso política. Al decir de la Unione Internazionale dei Magistrati, «para el Juez se impone, pues, una posición de imparcialidad que represente la negación de toda posición parcial, apartamiento de todo interés particular, garantía de objetividad. Independencia significa no sujeción a los grupos de presión que obran al nivel del poder, apartamiento completo de los condicionamientos, las influencias de las fuerzas interesadas en inclinar el fiel de la balanza de las decisiones ${ }^{19}$.

Por su parte, los Principios de Bangladore sobre la conducta judicial ${ }^{20}$ (2002), formulados para garantizar y promover su independencia, establecen, en relación con ese valor de la independencia judicial, que el juez debe ser independiente respecto de la sociedad en general y ha de estar, además, libre de conexiones e influencias inapropiadas con los poderes ejecutivo y legislativo y esto porque, como dice su preámbulo, una judicatura independiente e imparcial es esencial

16 J. Gabaldón López (1971), «Independencia judicial y seguridad jurídica», La Ley, 11025. A. Gallego Anabitarte (1971), Administración y jueces: gubernativo y contencioso, Madrid: Instituto de Estudios Administrativos.

17 En la doctrina americana, Owen Fiss defiende diferentes niveles o grados de independencia, al objeto de justificar las interferencias que el juez americano puede recibir de los poderes públicos. Sin embargo, como hemos visto, el modelo americano de nombramiento político del juez resulta incompatible con la tradición continental de la separación de poderes. O. Fiss (1993), "The Right Degree of Independence», en I. Stotzky, The Role of the Judiciary in the Transition to Democracy in Latin America, pág. 55. R. Posner (2008), How Judges think. Cambridge, Massachusetts: Harvard University Press. (1980) Il Giudice nella nuova Società. Unione Internazionale dei Magistrati, Roma, pág. 20.

20 El borrador del Código de Bangalore sobre la Conducta Judicial de 2001, aprobado por el Grupo Judicial de Reforzamiento de la Integridad Judicial, tal y como fue revisado en la Reunión en Mesa Redonda de Presidentes de Tribunales Superiores celebrada en el Palacio de la Paz de La Haya, Países Bajos, los días 25 y 26 de noviembre de 2002. 
cuando sus integrantes están llamados a desempeñar su papel de defensores «del constitucionalismo y del principio de legalidad», siendo la confianza pública en el sistema judicial «y en la autoridad moral y la integridad del poder judicial [...] de extrema importancia en una sociedad democrática moderna ${ }^{21}$.

La doctrina italiana defiende que la independencia subjetiva del juez es una noción consolidada ${ }^{22}$. Sin embargo, objetivamente resulta difícil de admitir la independencia subjetiva y la neutralidad ideológica del juez que ha participado en actividad política. Más difícil resulta la confianza social en ese juez, cuyas decisiones se interpretarán por el justiciado y la opinión pública en clave política. Es más, puede que incluso el juez se vea condicionado por este hecho y adopte sus decisiones en un exceso de celo, a los efectos de evitar que su decisión pueda ser interpretada por su histórica vinculación política; en ese caso, el juez ya no actúa con independencia.

El poder ejecutivo tiene instrumentos indirectos para intervenir en la justicia: la fiscalía y la abogacía del Estado en supuestos puntuales han sido instrumentos al servicio del Gobierno para defender sus intereses ${ }^{23}$; y no digamos el estatuto jurídico de la judicatura: el sistema de retribuciones o la movilidad ${ }^{24}$. La última encuesta a jueces y magistrados en servicio activo del CGPJ en Espańa (2015) arroja el dato de que un $9 \%$ de jueces y magistrados del orden penal que han instruido o juzgado asuntos de corrupción afirman haber recibido presiones ${ }^{25}$.

Sin embargo, unas décadas después se aprecia una problemática adicional: en un contexto de evidente descrédito de la actividad política, existen jueces y magistrados que abandonan la judicatura para formar parte de gobiernos y parlamentos. Este extremo nos debería obligar a pensar cuáles pueden ser los motivos de este cambio de situación administrativa: ¿qué hace que un juez, con su autoridad y prestigio, se integre en un partido político para desarrollar una carrera tan alejada de la judicatura?

En sede jurisprudencial no son pocas las sentencias que invocan la importancia de la separación de poderes y de la independencia judicial. Por su especial

21 Oficina de las Naciones Unidas contra la droga y el delito (UNODC) (2013), Comentario relativo a los Principios de Bangalore sobre la conducta judicial, Nueva York: Naciones Unidas.

22 B. Ponti (2012), Independenza del dirigente e funzione amministrativa, Santarcangelo di Romagna: Maggioli editore, pág. 19.

23 J. Villegas (2016), El poder amordazado. La historia oculta de cómo el poder politico se ha infiltrado en la justicia española, Madrid: Atalaya.

24 Sosa Wagner se refiere gráficamente a que los partidos políticos de la democracia arruinaron las esperanzas concebidas por la Constitución. F. Sosa Wagner (2016), La independencia del Juez: ¿una fábula? Madrid: La Esfera de los libros, pág 65.

25 Consejo General del Poder Judicial (2015), Encuesta de ámbito nacional a todos los jueces y magistrados en activo, pág. 79. 
trascendencia y simbolismo ${ }^{26}$, el Tribunal Constitucional, en Sentencia 37/2012 de 19 de marzo de 2012 (rec. 9689/2009) ${ }^{27}$, analiza la constitucionalidad del art. 100.7 LJCA, que establece el carácter vinculante de la doctrina legal sentada por la Sala de lo Contencioso Administrativa del Tribunal Supremo al resolver un recurso de casación en interés de ley.

Con ocasión de debatir si se vulnera la independencia judicial de los órganos judiciales inferiores en grado, el Tribunal Constitucional considera que el principio de independencia judicial es consustancial a todo Estado democrático, y su reconocimiento en España tiene origen en la Constitución de Cádiz de 1812 (FD cuarto):

La independencia del poder judicial, que se predica de todos y cada uno de los jueces y magistrados en cuanto ejercen la función jurisdiccional, implica que, en el ejercicio de esta función, están sujetos única y exclusivamente al imperio de la ley, lo que significa que no están ligados a órdenes, instrucciones o indicaciones de ningún otro poder público, singularmente del legislativo y del ejecutivo. E incluso que los órganos judiciales de grado inferior no están necesariamente vinculados por la doctrina de los Tribunales superiores en grado, ni aun siquiera por la jurisprudencia del Tribunal Supremo, con la excepción, de la que seguidamente nos ocuparemos, de la doctrina sentada en los recursos de casación en interés de ley; todo ello sin perjuicio de hacer notar que toda jurisprudencia del Tribunal Supremo, órgano jurisdiccional superior en todos los órdenes salvo lo dispuesto en materia de garantías constitucionales (art. 123.1 CE), complementa el ordenamiento jurídico, conforme señala el art. 1.6 del Código civil, y tiene, por ello, vocación de ser observada por los Jueces y Tribunales inferiores, en los términos que después se expresan, a lo que ha de ańadirse que la infracción de la jurisprudencia constituye motivo de casación en todos los órdenes jurisdiccionales.

A mayor abundamiento y como hemos anticipado, el Tribunal Constitucional destaca la vertiente subjetiva de la independencia judicial al decir que la misma es atributo consustancial a la función de juzgar, en cuanto implica que jueces y tribunales no están subordinados en el ejercicio de su función jurisdiccional a ningún otro poder público, sino sometidos única y exclusivamente «al imperio de la ley", esto es, sujetos al derecho. Esto significa que, a diferencia de lo que acontece con los poderes legislativo y ejecutivo, que disponen legítimamente de un amplio margen (siempre dentro del ordenamiento jurídico, como advierte el art. 9.1 CE) para adoptar de manera discrecional decisiones políticas, los jueces y tribunales integrantes del poder judicial no pueden ejercer su función jurisdiccio-

26 Pleno del Tribunal Constitucional reunido en Cádiz, en el Oratorio de San Felipe Neri, el día en que se cumplen doscientos años de la promulgación de la Constitución española de 1812.

27 Sentencia analizada in extenso por J. E. Soriano García, El poder, la Administración... op. cit., págs. 35-46. 
nal con discrecionalidad política ni según su libre albedrío, sino que han de juzgar sometidos al imperio de la ley, con sujeción al sistema de fuentes establecido.

En este sentido, el Tribunal Constitucional acuña un nuevo principio constitucional, cual es el de juridicidad, distinto al principio de legalidad, más amplio que este último y al que se refiere la Sentencia 133/1995, de 23 de septiembre (FD quince):

[...] la independencia judicial de cualquier presión o influencia externa tiene como anverso el sometimiento exclusivo de los Jueces a la Ley y al Derecho, principio de juridicidad, más allá del de legalidad, que implica el respeto no sólo a las normas sino también a los usos y costumbres, a los principios generales del Derecho y a la doctrina legal del Tribunal Supremo con valor complementario del ordenamiento jurídico.

A día de hoy vemos en España sucesos impensables hasta hace poco: la publicación de declaraciones, incluso en causas declaradas secretas, genera una opinión pública que tiende a influir en la decisión judicial; se celebran manifestaciones ante sedes judiciales y aparecen pintadas en el domicilio particular de algún juez; se vierten opiniones acerca de la actuación de jueces y magistrados en medios audiovisuales o en prensa escrita, sin conocer el asunto; en definitiva, continuamente afloran tentaciones para lesionar la independencia de la función judicial $^{28}$.

\section{NEUTRALIDAD IDEOLÓGICA DEL JUEZ}

La independencia de la función judicial obedece a la necesidad de generar confianza y credibilidad a la actuación del juez. En este sentido, la independencia frente a los factores capaces de mediatizarla contribuye a la aplicación del derecho sin más, objetiva y libre de injerencias, incluso dentro del mismo poder judicial.

La actuación del juez no puede estar comprometida ni por factores externos (órdenes, instrucciones, sugerencias) ni tampoco por elementos internos o personales del juez ${ }^{29}$ que puedan llevarle a un pronunciamiento emotivo ${ }^{30}$.

Que el juez tenga su propia ideología resulta natural, evidente e incuestionable. Otra cosa es si su ideología puede afectar y hasta distorsionar su valoración y toma de decisión. Todo dependerá de la intensidad con la que ejerza su ideología:

28 J. M. Fernández Pastrana (1991), «La “otra” independencia de los Jueces», Actualidad Administrativa 10, 10 de mayo.

29 J. Nieva Fenoll (2019), «Trasfondo psicológico de la independencia judicial», en J. Nieva Fenoll y E. Oteiza (dirs), La independencia judicial: un constante asedio. Madrid: Marcial Pons, págs. 23 a 39. D. Simon (1985), La independencia del Juez, Barcelona: Ariel, pág. 169.

30 A. Forza, R. Rumiati y G. Menegon (2017),. Il giudice emotivo, Bologna: Il Mulino Guide. 
si se limita a votar como ciudadano, o si, por el contrario, participa activamente en la defensa de una opción ideológica frente a otras, a las que censura y critica públicamente.

El ordenamiento jurídico contempla el principio de neutralidad ideológica, común a todos los servidores públicos, que cobra mayor importancia en jueces y magistrados por la sensibilidad de la función judicial.

En Italia el debate sobre la exhibición de crucifijos en las escuelas ha sido especialmente intenso, hasta el punto de que el TEDH ha virado completamente su criterio entre 2009 y 2011. En este sentido, inicialmente en Lautsi c. Italia I (Sentencia de 3 de noviembre de 2009), el TEDH entiende que para asegurar un entorno libre era necesario prohibir todo signo religioso ostensible; lo que, aplicado al crucifijo, implicaba la eliminación de un símbolo religioso de aceptación mayoritaria para no perturbar a ateos, agnósticos o laicos recalcitrantes, que eran, frente a aquellos, una minoría. Sin embargo, en Lautsi c. Italia II (Sentencia de 18 de marzo de 2011), el TEDH aceptó que la admisión o no de símbolos religiosos en la escuela quedaba dentro del ámbito de las decisiones legítimas del Estado y concluyó que la simple presencia del crucifijo como símbolo de la religión a la que pertenece la mayoría de la población no debe entenderse como adoctrinamiento en la escuela pública ${ }^{31}$.

En España la neutralidad ideológica del juez ha sido analizada y debatida en la Sentencia del Tribunal Supremo, Sala Tercera, de lo Contencioso-administrativo, 2614/2016, de 14 de diciembre de 2016 (rec. 264/2015). Esta Sentencia confirma la sanción de tres años de suspensión al magistrado de la Audiencia Provincial de Barcelona Santiago Vidal impuesta por Acuerdo del Consejo General del Poder Judicial de 26 de febrero de 2015.

El caso, de sobras conocido por su trascendencia mediática, consiste en la redacción de una constitución catalana por el magistrado en activo. Los hechos probados de la Sentencia ponen de relieve las connotaciones político-ideológicas de la actuación del juzgador:

1. Finalidad política, que no científica, de la redacción de la constitución catalana, de ponerla a disposición, o exponerla como modelo de quienes habían promovido tanto la celebración de una consulta popular (el llamado «derecho a decidir») como la independencia de Cataluña.

2. Reiteración, por cuanto el magistrado intervino en más de cien actos públicos, organizados o promovidos por la Asamblea Nacional Catalana y Omnium Cultural.

31 S. Muñoz Machado (2013), Los itinerarios de la libertad de palabra, Barcelona: Crítica, págs. 202 y 203. Véase también J. Weiler (2012), «Estado y Nación; Iglesia, Mezquita y Sinagoga: La sinopsis», El Cronista del Estado Social y Democrático del Derecho, 27, Iustel, págs. 28 y ss. y M. La Torre y D. Llamazares (2012), «Debate sobre Lautsi», El Cronista del Estado Social y Democrático del Derecho, 27, Iustel, págs. 34 y ss. 
3. Actitud reivindicativa del citado proceso y consulta, justificando y apoyando los mismos, transmitiendo a los asistentes confianza sobre la legalidad del proceso, y animando a su participación.

4. En ninguno de dichos actos ocultó su condición de magistrado de la Audiencia Provincial de Barcelona, en situación de activo. Es más, la suya no era una intervención cualquiera, sino la principal por su condición de miembro de la judicatura.

5. Todo ello se acompañaba de una escenificación política con lemas («ara és l'hora», "el país que volem»), banderas independentistas... en las que el magistrado formulaba propuestas de alteración del sistema de fuentes o incluso críticas al Tribunal Constitucional, que en aquel momento era el competente para decidir la suspensión y posteriormente la constitucionalidad o no de la consulta y de las resoluciones aprobadas por el Parlamento catalán.

El CGPJ sancionó al magistrado por una falta muy grave de ignorancia inexcusable en el cumplimiento de los deberes judiciales prevista en el art. 417.14 LOPJ.

De entre los diez motivos de impugnación, el actor fundamenta su recurso básicamente sobre la libertad de expresión («puro ejercicio de creación intelectual no encargado por nadie, ni tampoco efectuado en edificios o instalaciones judiciales u oficiales») y que la actuación sancionada no formaba parte de su función jurisdiccional.

Sin embargo, el Tribunal Supremo rebate ambos argumentos sobre la base de que un juez debe generar confianza a los ciudadanos de que su actuación no se verá empañada por otros factores ajenos a la lealtad constitucional.

En primer término, la sentencia (FD séptimo) recuerda el valor de la Constitución como norma jurídica, y que como tal tiene un procedimiento de reforma previsto en el título X:

[...] debe de decirse que la principal idea que la Constitución comprende no es sólo un texto jurídico que define la estructura del Estado, el cometido que corresponde a sus principales poderes u órganos y los derechos que los ciudadanos pueden hacer valer frente al propio Estado; comporta algo más: la identificación de quién es el concreto sujeto colectivo que democráticamente la aprueba y en cuya voluntad se asienta el principal fundamento de su validez jurídica.

Esta idea de Constitución va, pues, aparejada a todo lo siguiente: a la idea de soberanía (equivalente a la superior capacidad o poder de constituir y autoorganizar una comunidad política diferenciada e independiente de cualquier otra); a la identificación del concreto sujeto colectivo que ostenta la titularidad de ese poder soberano; y a la delimitación del territorio en el que quedará circunscrita esa comunidad política diferenciada que se erige en Estado independiente y distinto de cualquier otro.

Siguiendo con este razonamiento, en su FD noveno la sentencia recuerda que el Estado de derecho se asienta en un modelo de organización social y 
constituye un orden de convivencia plasmado en normas vinculantes para todos, ciudadanos y poderes públicos.

En relación a la libertad de expresión, entiende que el Estado de derecho faculta para exteriorizar opiniones contrarias al mismo, pero no tolera, por parte de quienes ostentan poderes públicos, comportamientos contrarios a sus mandatos imperativos, ni tampoco acciones dirigidas a su modificación al margen de los procedimientos de elaboración normativa establecidos en la Constitución y el resto del ordenamiento jurídico.

Destaca que el juez, en tanto que servidor público con una función específica y sensible de juzgar y ejecutar lo juzgado, no puede atentar contra el modelo de convivencia que configura el Estado de derecho. Así, la efectiva vigencia de ese modelo de convivencia que es el Estado de derecho hace imprescindible - para el Alto Tribunal — una colaboración social y un sentimiento colectivo favorable a la misma, que pasa por hacer bien visible que aquellas conductas realizadas en contradicción con el ordenamiento no son jurídicamente irrelevantes o indiferentes; $y$, sobre todo, que resultan de manera muy especial constitucionalmente intolerables en jueces y magistrados, por encarnar el poder público que la Constitución configura como principal garante de que el derecho consista, efectivamente, en un orden de convivencia obligatorio y vinculante.

En relación a si los deberes de neutralidad e independencia del juez solo son predicables en el ejercicio de su función judicial, el Tribunal Supremo no tiene duda alguna al afirmar que estos deberes trascienden esta función estricta de juzgar y que se proyectan a cualquier otra actuación, incluso privada. En consecuencia, considera que el juramento o promesa de deber de guardar la Constitución que prestan los miembros de la Carrera Judicial ex art. 318 LOPJ, no se trata de una simple fórmula o ceremonia litúrgica vacía de contenido,

[...] pues constituye el compromiso jurídico asumido por el juez sobre la observancia de la Constitución en la totalidad de sus comportamientos que guarden relación con ese papel que constitucionalmente tiene asignado de ser el principal garante del Estado de Derecho; esto es, no sólo cuando actúe en el ejercicio de la potestad jurisdiccional, sino también en todas sus actuaciones externas que puedan generar en la ciudadanía una desconfianza, no solamente en la Administración de Justicia (según ya declaró la sentencia de esta Sala 14 de julio de 1999, dictada en el recurso 617/1999), sino también en la efectiva o real vigencia del orden jurídico «obligado y vinculante» en que esencialmente consiste el modelo de convivencia que es el Estado de Derecho.

Pone especial énfasis en que este deber de lealtad constitucional por parte de jueces y magistrados no se circunscribe a su estricta actuación jurisdiccional; antes al contrario, el compromiso asumido a través del juramento o promesa resulta configurado, en el art. 322.1 LOPJ, como un requisito inexcusable para la pertenencia a la magistratura, de manera tal que la negativa a prestarlo «se entenderá una renuncia al cargo y a la Carrera Judicial». 
Para el Alto Tribunal, la observancia de la Constitución es el primer y principal deber judicial del estatuto jurídico aplicable a jueces y magistrados; un deber estatutario, recuerda, que se asume libremente cuando voluntariamente se accede a la carrera judicial.

Insiste la sentencia en que la pertenencia a la magistratura condiciona el comportamiento de sus miembros en conductas y comportamientos ajenos a la función judicial:

Por todos estos motivos la sentencia desestima el recurso y confirma el acuerdo impugnado.

La sentencia cuenta con un voto particular concurrente formulado por el magistrado Excmo. Sr. Sieira Míguez, que se refiere a la neutralidad política. Considera que los jueces tienen un deber de mantener hacia el exterior una postura pública de neutralidad política, y que ese deber resulta de los artículos 117 y 127 CE y del 395 de la LOPJ, en cuanto establece entre otras prohibiciones que no podrán los jueces o magistrados concurrir en su condición de miembros del Poder Judicial, o cualesquiera actos o reuniones públicas que no tengan carácter judicial, excepto aquellas que tengan por objeto cumplimentar al Rey o para las que hubieran sido convocados o autorizados por el Consejo General del Poder Judicial, a lo que ha de unirse al hecho de que a los jueces o magistrados en época electoral la única actividad que les está permitida es la mera emisión del voto (art. 395.2 LOPJ), y si eso es así y tal limitación a la adopción de posturas políticas de manera pública no es excepcionable en los períodos de máxima participación política de los ciudadanos, con más razón debe aplicarse en otros periodos temporales con un nivel de vivencia política muy inferior.

No acaba aquí la consideración anticonstitucional de la actuación del magistrado. En efecto, una vez expirado el plazo de tres años de suspensión de funciones, el Sr. Vidal solicitó el reingreso a la carrera judicial. El CGPJ, con base en el art. 367.1 LOPJ, consideró que no superaba el juicio de aptitud para el reingreso en el servicio activo porque, durante el tiempo de suspensión, alardeó en diferentes actos públicos de los hechos constitutivos de infracción disciplinaria. Para el CGPJ, la actuación pública de Santiago Vidal durante el tiempo de cumplimiento de la suspensión «implica una evidente perturbación a la reputación e imagen del Poder Judicial» y refleja «su falta de lealtad a las instituciones del Estado y a la Constitución, que no sólo decide públicamente no acatar sino también hacer proselitismo de su desobedecimiento, incluso haciendo ostentación de su condición de juez».

Otra cosa es que el Tribunal Constitucional, en Sentencia 135/2018, de 13 de diciembre de 2018, anuló esta declaración de aptitud por inconstitucionalidad del art. 367.1 LOPJ, de manera que el Tribunal Supremo, en Sentencia de 12 de 
marzo de 2019, estimó el recurso del Sr. Vidal frente a la denegación del reingreso por parte de la Comisión Permanente del CGPJ ${ }^{32}$.

\section{CONFIANZA SOCIAL EN EL JUEZ}

La confianza social en los tribunales de justicia se configura como un elemento esencial del sistema democrático. De hecho el deber de lealtad constitucional que el juez asume en su promesa o juramento del art. 318.1 LOPJ implica la abstención de conductas que puedan quebrantar aquella confianza.

La Sentencia del Tribunal Supremo 2614/2016 que venimos comentando, destaca sobre manera el elemento de la confianza social que debe inspirar el juez. De alguna manera distingue la posición del juez en el ordenamiento jurídico, con un plus de relevancia superior a la de cualquier servidor público. De ahí que su actuación ajena a la función judicial revista tal importancia.

En un extenso voto particular a esta sentencia, el magistrado Excmo. Sr. Menéndez Pérez, al que se adhiere el Excmo. Sr. Arozamena Laso, sitúa la neutralidad política en el centro de la independencia judicial y la imparcialidad del juez. Ambas son las notas más características o las que definen la esencia misma de la función jurisdiccional, consistente en la resolución de los conflictos jurídicos de los que deban conocer los juzgados y tribunales con exclusiva sumisión a la ley.

Ahora bien, a juicio de estos magistrados, no basta con la situación o estado de efectiva y real independencia e imparcialidad, sino que - tan importante como su existencia material - deviene imprescindible la percepción de los ciudadanos de que esto es así, lo que equivale a la confianza social de que la función jurisdiccional se ejerce con estricta sujeción a lo que constituye su esencia.

No muy distinto es el caso enjuiciado por el Tribunal Supremo, Sala Tercera, de lo Contencioso-administrativo, en Sentencia de 17 de abril de 2002 (rec. 466/2000), que confirma las sanciones de suspensión de un año y de separación de la carrera judicial a una magistrada de la Audiencia Provincial de Málaga, que no se abstuvo en asuntos que afectaban a su padre y a su hermano.

Esta Sentencia destaca el prestigio de los tribunales de justicia y la confianza social en los mismos:

[...] es un rasgo sustancial de la configuración estructural del Poder Judicial en la Constitución, que está constituido por el prestigio que ante la ciudadanía han de presentar los Tribunales para que no se quiebre la confianza social en la Administración de Justicia, y por ser dicha confianza un pilar importantísimo para la real vivencia y eficacia de los postulados del Estado democrático de Derecho (FD octavo).

32 El Sr. Vidal tiene en estos momentos la condición de investigado en el Juzgado de Instrucción número 13 de Barcelona, que abrió diligencias por presuntos delitos de malversación de fondos públicos, desobediencia al Tribunal Constitucional, prevaricación y revelación de secretos en relación con los preparativos del referéndum independentista del 1-O. 
Por último, la Sentencia del Tribunal Supremo citada de 14 de julio de 1999 , en un caso en que un magistrado publica en un diario de tirada nacional hasta tres artículos de opinión que contienen expresiones ofensivas ${ }^{33}$, recuerda que la fórmula de "guardar y hacer guardar» fielmente la Constitución condensa no solo la función propiamente jurisdiccional (hacer guardar), sino también un compromiso de conducta personal mientras se ostente ante la sociedad la titularidad de la potestad jurisdiccional (guardar).

En relación a las críticas formuladas entre jueces, el TEDH con carácter general considera que el honor de jueces y magistrados constituye un límite a la libertad de expresión (Sentencia de 9 de julio de 2013, caso Di Giovanni contra Italia), y solo en casos delictivos entiende que los ciudadanos tienen derecho a conocer el funcionamiento anormal de la justicia (Sentencia de 26 de febrero de 2009, caso Kudeshkina contra Rusia).

\section{LIBERTAD DE EXPRESIÓN DEL JUEZ}

Es evidente que un juez, como cualquier ciudadano, goza del derecho a la libertad de expresión (arts. 20.1.d CE y arts. 21 C.It). Sin embargo, no puede desconocerse que el juez, por la especial relevancia de la labor que ejerce, tendrá unos límites superiores a los de cualquier ciudadano, incluso de cualquier servidor público.

En efecto, jueces y magistrados son simultáneamente empleados públicos y titulares de un poder del Estado. Esto explica que su estatuto jurídico personal comprenda dos grupos de deberes: unos, comunes a los de los funcionarios, y referidos a la vertiente puramente profesional de su dedicación; y otros que les son específicos o singulares, y que van ligados a la relevancia constitucional del cometido que les corresponde dentro del Estado.

De hecho la singular posición del juez como titular de un poder del Estado limita su libertad de expresión. No en vano la Sentencia del Tribunal Supremo, Sala Tercera, de lo Contencioso-administrativo, de 20 de noviembre de 2008

33 El recurso se dirige contra el acuerdo del Pleno del Consejo General del Poder Judicial de 4 de noviembre de 1998, que impuso al demandante, presidente de la Sección $10^{\text {a }}$ de la Audiencia Provincial de Madrid, tres sanciones. La primera de esas sanciones fue una multa de 500000 ptas., por la comisión de una falta grave del art. 418.1 de la Ley Orgánica del Poder Judicial, derivada de la falta de respeto a los magistrados de la Sala Segunda del Tribunal Supremo, realizada en el artículo periodístico «Bula de oro para un prócer», publicado en el diario El Mundo el 24 de marzo de 1998. Y las otras dos sanciones fueron multas de 50000 ptas., por la comisión, en dos ocasiones, de la falta leve del art. 419.2 de la citada ley, a causa de la desconsideración con los magistrados de los Juzgados Centrales de Instrucción números 5 y 2, a través, respectivamente, de los artículos periodísticos «Cainismo y prevaricacion» y "Panorama desde el puente», publicados en el antes mencionado diario los días 9 de septiembre y 27 de octubre de 1997. 
(rec. 339/2005) no niega, pero sí aconseja no hacer uso de la libertad de expresión cuando un juez ha sido objeto de críticas:

[...] cuando un Juez o Tribunal es cuestionado por los medios de comunicación social o por los actores políticos, por razones relacionadas con el ejercicio de su actividad jurisdiccional, las limitaciones estatutarias que afectan a jueces y magistrados en relación con la libertad de expresión, aconsejan que no rectifiquen utilizando los mismos cauces, pues tienen a su disposición los medios institucionales adecuados para rectificar las informaciones erróneas difundidas por la prensa, o determinadas declaraciones o afirmaciones que pongan en entredicho su integridad e independencia. Aun siendo esto lo conveniente, como parece ponerlo de manifiesto el presente proceso, también lo es que puede el Juez o Magistrado ejercer las acciones penales o civiles que estime conducentes.

El Tribunal Supremo, Sala Tercera, de lo Contencioso-administrativo, Sección 4a, en Sentencia 855/2018 de 24 de mayo de 2018 (rec. 2520/2016), analiza la sanción de advertencia impuesta al magistrado recurrente por haber vertido manifestaciones sarcásticas contra el ponente en unas diligencias sobre las instrucciones de señalamientos en el juzgado del que era titular y en las que informó negativamente su solicitud de comisión de servicios.

El Alto Tribunal entiende que el derecho a la libertad de expresión dispone de un campo de acción que viene solo delimitado por la ausencia de expresiones indudablemente injuriosas o sin relación con las ideas u opiniones que se expongan y que resulten innecesarias para la exposición de las mismas (SSTC, entre otras, 105/1990, de 6 de junio; 42/1995, de 13 de febrero; 112/2000, de 5 de mayo; 99/2002, de 6 de mayo; 181/2006, de 19 de junio ; 9/2007, de 15 de enero; 139/2007, de 4 de junio; o 56/2008, de 14 de abril). Asimismo, es doctrina constitucional la que afirma que hay sectores o grupos de ciudadanos sometidos a límites más estrictos o específicos en cuanto al ejercicio del derecho a la libertad de expresión por razón de la función que desempeñan (STC 270/1994, de 17 octubre).

Uno de esos sectores es, al decir de la Sentencia, el de los jueces y magistrados en sus relaciones con los órganos de gobierno del Poder Judicial, pues las funciones de gobierno asignadas a estos son necesarias para alcanzar la mejor organización posible de los juzgados y tribunales del ámbito territorial en que las ejercen y, consiguientemente, para la mejor y más eficaz prestación a la sociedad de la función constitucional que estos tienen atribuida. Por ello, el ejercicio del derecho de libertad de expresión en esas relaciones debe quedar sometido al límite más estricto o específico de que con él no se ponga en riesgo o se dañe innecesariamente la confianza que aquella ha de tener de que es ese y no otro el fin perseguido en todo caso.

El TEDH ha tenido ocasión de interpretar el art. $10 \mathrm{CEDH}$, relativo a la libertad de expresión, para el caso concreto de jueces y magistrados. Así, en la decisión de inadmisibilidad de 8 de febrero de 2001, caso Pitkevich contra 
Rusia, considera que las actuaciones de una jueza que hacía proselitismo de una opción religiosa en el ejercicio de su función judicial (llegó a prometer sentencias favorables a justiciables si se unían a su credo) minan el deber de apariencia de imparcialidad y cuestionan la autoridad judicial, de manera que la expulsión de la carrera judicial no resulta contraria a la libertad de expresión.

Sí forman parte de la libertad de expresión, según el TEDH, las críticas técnico-jurídicas que puedan dirigir jueces y magistrados al derecho positivo o a reformas proyectadas, aunque coincidan con manifestaciones vertidas por grupos políticos. Puede citarse en este sentido la Sentencia de 28 de octubre de 1999, caso Willie contra Liechenstein, en la que el presidente del Tribunal Administrativo de ese pincipado propuso en una conferencia en la universidad que el Tribunal Constitucional pudiera intervenir en los conflictos entre todos los órganos, incluyendo al príncipe, que goza de inmunidad de jurisdicción. El magistrado no fue renovado en su cargo y el TEDH consideró que su intervención estaba amparada por la libertad de expresión.

En este mismo sentido, la Sentencia de 23 de junio de 2016, caso Baka contra Hungría, considera que se ha vulnerado el derecho a la libertad de expresión al presidente del Tribunal Supremo de Hungría, al que no se le renovó en su cargo por haber formulado alegaciones a un proyecto normativo que afectaba a la judicatura.

\section{INSUFICIENCIAS DEL DERECHO POSITIVO}

Como decimos, las constituciones han asumido el esfuerzo de deslindar las fronteras de lo judicial a partir del establecimiento de sus rasgos diferenciales, especialmente con los poderes ejecutivo y legislativo ${ }^{34}$.

Otra cosa es que el derecho positivo no contemple en España y con matices en Italia el caso que comentamos del alto órgano o parlamentario que reingresa a la carrera judicial, por cuanto se limita a fijar una incompatibilidad entre el servicio activo en la judicatura y el ejercicio de acciones políticas, pero no prevé si el reingreso después de un mandato político puede empañar la neutralidad ideológica y en última instancia la independencia en el ejercicio de la función judicial.

Italia y España han sufrido de forma muy pareja el drama de la corrupción. Ambos Estados han respondido con sendas leyes en materia de transparencia, si bien la normativa italiana ha abordado con mayor profundidad el ejercicio en términos de imparcialidad de la función pública ${ }^{35}$.

34 L. Del Río Fernández (2007), «Independencia judicial y separación de poderes», Diario La Ley, 6838, Año XXVIII, 11 de diciembre.

35 Desde la promulgación de la ley sobre transparencia, Italia ha pasado de la posición 72 en 2012 a la 54 en 2018. Sin embargo, y de manera paradójica, Espańa ha retrocedido dos puntos, pasando de la posición 40 en 2013 a la 42 en 2018. 


\section{ORDENAMIENTO ITALIANO}

Quizá sea Italia un ordenamiento al que España debe mirar para afrontar una decidida reforma del estatuto jurídico de jueces y magistrados, dada su experiencia sobre inadecuación de nombramientos en la Administración pública.

En efecto, la Ley 190, de 6 de noviembre de 2012, de disposiciones para la prevención y la represión de la corrupción y de la ilegalidad en la Administración Pública $^{36}$ (conocida como la Ley Severino por el nombre de la ministra de Justicia que la impulsó, Paola Severino) responde a una serie de exigencias internacionales de abordar la lucha contra la corrupción ${ }^{37}$.

La Ley 190 fue desarrollada por tres decretos legislativos ejecutivos: el Decreto legislativo 33, de 14 de marzo de 2013, de reorganización de las disposiciones aplicables a la obligación de publicidad, transparencia y difusión de la información por parte de las Administraciones públicas ${ }^{38}$, el Decreto legislativo 39, de 8 de abril de 2013, por el que se dictan disposiciones en materia de inadecuación de los nombramientos y de las incompatibilidades de los cargos en las Administraciones públicas y en el seno de entidades privadas con participación pública, de conformidad con el art. 1, apdos. 49 y 50 de la Ley 190 de 6 de noviembre de $2012^{39}$ y el Decreto legislativo 235, de 31 de diciembre de 2012, por el que se aprueba el texto consolidado de las disposiciones sobre el incumplimiento y la prohibición de ocupar cargos electivos y gubernamentales resultantes de sentencias definitivas de condenas por delitos no culpables, de conformidad con el art. 1, párr. 63 de la Ley 190 de 6 de noviembre de $2012^{40}$.

La Ley 190 y sus decretos legislativos impulsan en consecuencia medidas de publicidad, transparencia y difusión de la información por parte de las Administraciones públicas, así como el régimen novedoso de inadecuación de nombramientos y de incompatibilidades de los cargos de las Administraciones públicas y en el seno de entidades privadas con participación pública ${ }^{41}$. Estas medidas principales se complementan con la abolición de la autoridad para los contratos

36 Gazzetta Ufficiale, 265, 13 de noviembre de 2012.

37 S. Bonfigli «L'Italia e le politiche internazionali di lotta alla corruzione», en F. Merloni y L. Vandelli, La corruzione amministrativa. Cause, prevenzione e rimedi, Bolonia: Il Mulino, págs. 109 y ss. Estos instrumentos son el Convenio penal sobre la corrupción del Consejo de Europa, hecho en Estrasburgo el 27 de enero de 1999 y ratificado en Italia por la Ley 110 de 2012, y la Convención de las Naciones Unidas contra la corrupción (UNCAC), conocida como Convención de Mérida, que fue aprobada por la Asamblea General de la ONU el 31 de octubre de 2003 con la resolución 58/4 y ratificada en Italia con la Ley 116 de 3 de agosto de 2009.

38 Gazzetta Ufficiale, 80, de 5 de abril de 2013.

39 Gazzetta Ufficiale, 92, 19 de abril de 2013.

40 Gazzetta Ufficiale, 3, 4 de enero de 2013.

41 F. Marini (2018), "Corrupción en Italia: el antes y el después de la reforma Severino», Revista Internacional Transparencia e Integridad, 7. 
públicos con la transferencia de las competencias a la Autoridad Nacional Anticorrupción, reforzada al mismo tiempo en lo que respecta a su papel y funciones en materia de transparencia y de prevención de la corrupción (Decreto Legislativo 90 de 2014, convertido en la Ley 114 de 2014 9); la reforma de la normativa en materia de transparencia administrativa, en el marco de las políticas generales de reforma administrativa (la denominada reforma "Madia»), mediante la Ley 124 de 2015 y sobre todo con el posterior Decreto Legislativo delegado 97 de 2016; el nuevo Código de la Contratación Pública, aprobado mediante el Decreto Legislativo 50 de 2016 y recientemente revisado y corregido por el Decreto Legislativo 56 de $2017^{42}$.

De todas estas disposiciones, en lo que a nosotros interesa, debe destacarse el Decreto Legislativo 39, que viene a fortalecer la imparcialidad de los servidores públicos y a evitar conflictos de intereses. En efecto, esta norma distingue la actuación entre los órganos políticos y los órganos directivos de la Administración, reservando para los primeros los actos de dirección de la acción administrativa, mientras que a los segundos se les encomiendan los actos de gestión y de actuación específica para los ciudadanos.

El régimen jurídico de la imparcialidad de los empleados públicos descansa sobre tres premisas: los códigos de conducta, las incompatibilidades y la denominada inadecuación de los nombramientos.

\subsection{Códigos de conducta}

La experiencia italiana en materia de códigos de conducta (codice di comportamento) se remonta al Decreto Legislativo 29/1993, de 3 de febrero, de racionalización de la organización de las Administraciones públicas y revisión de la disciplina referente al empleo público ${ }^{43}$.

En aplicación del art. 58 bis de esta norma ${ }^{44}$, el Comité Directivo Central de la Asociación Nacional de Magistrados aprueba el Código Ético de los Magistrados Ordinarios Italianos, según el cual —entre otras declaraciones progra-

42 E. Carloni (2017), «El sistema de la lucha contra la corrupción en Italia. Características, tendencias y problemas abiertos", Revista de Estudios de la Administración Local y Autonómica, 7, págs. 87 y 88. G. Fiandaca y E. Musco (2013), Diritto penale. Parte speciale, vol. 1. La recente reforma dei reati contro la pubblica amministrazione. P. Bertazzoli (2013), Anticorruzione: Modalità operatie e piano triennale per gli enti local (L. 190/2012).

43 GU Serie Generale, 119 del 25-05-1998 - Suppl. Ordinario 98. F. Merloni (2013), «I piani anticorruzione e i codici di comportamento", Diritto Penale e Processo, 8S, págs. 4 y ss.; B. G. Mattarella (1996), «I codici di comportamento», Rivista giuridica del lavoro, págs. 275 y ss.; E. Carloni (2002), «Ruolo e natura dei c.d. 'codici etici' delle pubbliche amministrazioni», Diritto pubblico, págs. 319-361.

44 Precepto introducido por el Decreto Legislativo 546/1993, de 23 de diciembre. (GU Serie Generale, 304 del 29-12-1993 - Suppl. Ordinario, 123). 
máticas - en la vida social el magistrado se comporta con dignidad, corrección, sensibilidad al interés público. En el desarrollo de sus funciones y en todo comportamiento profesional el magistrado se debe inspirar en valores de desinterés personal, de independencia y de imparcialidad (art. 1).

En lo referente a independencia, el Código Ético, en su art. 8, dispone que el magistrado garantiza y defiende el ejercicio independiente de sus funciones y mantiene una imagen de imparcialidad y de independencia. Evita cualquier implicación con centros de poder partidarios o de negocios que pueden condicionar el ejercicio de sus funciones o empañar de algún modo la imagen. No acepta encargos ni despliega actividades que obstaculizan el pleno y correcto desenvolvimiento de su función o que por la naturaleza, la fuente o la modalidad del otorgamiento puedan de algún modo condicionar la independencia.

Por último, en materia de imparcialidad, el art. 9 del Código Ético determina que en el ejercicio de las funciones obra para hacer efectivo el valor de la imparcialidad, empeñándose en superar los prejuicios culturales que puedan incidir sobre la comprensión y valoración de los hechos y sobre la interpretación y aplicación de las normas. Asegura que en el ejercicio de las funciones su imagen de imparcialidad esté siempre plenamente garantizada. A tal fin valora con el máximo rigor la concurrencia de situaciones de posible abstención por graves razones de oportunidad.

Los códigos de conducta fueron incorporados al régimen general de los empleados públicos mediante el Decreto Legislativo 165, de 30 de marzo de 2001, por el que se aprueban normas generales de ordenamiento del empleo en las Administraciones públicas ${ }^{45}$.

La Ley 190 ha dado nueva redacción al art. 54 del Decreto Legislativo 165 de 2001, introduciendo una serie de elementos innovadores ${ }^{46}$. En este sentido, el

45 G. U. 106, de 9 de mayo de 2001.

46 1. Il Dipartimento della funzione pubblica, sentite le confederazioni sindacali rappresentative ai sensi dell'articolo 43, definisce un codice di comportamento dei dipendenti delle pubbliche amministrazioni, anche in relazione alle necessarie misure organizzative da adottare al fine di assicurare la qualita' dei servizi che le stesse amministrazioni rendono ai cittadini.

2. Il codice e' pubblicato nella Gazzetta ufficiale e consegnato al dipendente all'atto dell'assunzione.

3. Le pubbliche amministrazioni formulano all'ARAN indirizzi, ai sensi dell'articolo 41, comma 1 e dell'articolo 70, comma 4, affinche' il codice venga recepito nei contratti, in allegato, e perche' i suoi principi vengano coordinati con le previsioni contrattuali in materia di responsabilita' disciplinare.

4. Per ciascuna magistratura e per l'Avvocatura dello Stato, gli organi delle associazioni di categoria adottano un codice etico che viene sottoposto all'adesione degli appartenenti alla magistratura interessata. In caso di inerzia il codice e' adottato dall'organo di autogoverno. 5. L'organo di vertice di ciascuna pubblica amministrazione verifica, sentite le organizzazioni sindacali rappresentative ai sensi dell'articolo 43 e le associazioni di utenti e consu- 
código de conducta enumera una lista de deberes establecidos por el Gobierno y posteriormente complementada por un documento adoptado por cada Administración, destinados a garantizar la imparcialidad del empleado público. Al decir de la doctrina italiana, el código de conducta viene a diseñar el estatuto constitucional del empleado público ${ }^{47}$.

Nótese que el código de conducta nace como una declaración meramente programática y en consecuencia distinto y ajeno a los deberes de los empleados públicos, cuyo incumplimiento daba lugar a responsabilidad disciplinaria ${ }^{48}$. Sin embargo, la reforma de 2012 presenta como principal novedad la tipificación como infracción disciplinaria del incumplimiento de los deberes de los códigos de conducta, reforzando en consecuencia su valor normativo como fuente del derecho ${ }^{49}$. De hecho una sanción prevista en los códigos de conducta es la pérdida de la condición de funcionario en caso de conducta particularmente grave o reiterada.

\subsection{Régimen de incompatibilidades}

Al objeto de evitar los conflictos de intereses, así como cualquier situación que afecte a la imparcialidad e independencia de los servidores públicos, el Decreto Legislativo 39 de 2013 regula el régimen de incompatibilidades.

En este sentido, esta norma dedica sus capítulos V y VI a establecer la incompatibilidad de los cargos directivos que implican poderes de supervisión sobre las entidades privadas controladas o financiadas, respecto de la aceptación y el ejercicio, durante el desempeño del cargo, de tareas y cargos en esas mismas entidades. Asimismo consideran los casos de incompatibilidad entre cargos ejecutivos en las empresas sanitarias y el ejercicio de actividades profesionales o de cargos en entidades privadas reguladas o financiados por el Servicio Regional de Salud; los supuestos, variados, de incompatibilidad entre las funciones directivas y de administración de una entidad pública y los cargos "políticos» a nivel estatal,

matori, l'applicabilita' del codice di cui al comma 1, anche per apportare eventuali integrazioni e specificazioni al fine della pubblicazione e dell'adozione di uno specifico codice di comportamento per ogni singola amministrazione.

6. Sull'applicazione dei codici di cui al presente articolo vigilano i dirigenti responsabili di ciascuna struttura.

7. Le pubbliche amministrazioni organizzano attivita' di formazione del personale per la conoscenza e la corretta applicazione dei codici di cui al presente articolo.

47 G. Sirianni, «Il profili costituzionali. Una nuova lettura degli articoli 54, 97 e 98 della Costituzione» en F. Merloni y L. Vandelli, (eds.), La corruzione amministrativa... op. cit. págs. 129 y ss.

48 B. G. Mattarella (2007), Le regole dell'onestà, Bolonia: Il Mulino; F. Merloni y R. Cavallo Perin (eds.) (2008), Al servizio della Nazione, Milán: Franco Angeli.

49 E. D’Alterio (2013), «I codici di comportamento e la responsabilità disciplinare», en B. G Mattarella y M. Pelissero, La legge anticorruzione, Torino: Giappichelli, págs. 25 y ss. 
regional y local; los supuestos de incompatibilidad entre la función de administrador de una entidad privada de control público y cargos políticos a nivel estatal, regional y local ${ }^{50}$.

\subsection{Inadecuación de nombramientos}

La verdadera innovación instaurada por la Ley 190 de 2012 y el Decreto Legislativo 39 de 2013 consiste en la institución de la inadecuación de nombramientos (inconferibilità di incarichi), que persigue trazar una «justa distancia» entre el gestor público y las funciones políticas activas ${ }^{51}$.

Este régimen se traduce en la práctica en la prohibición de ser nombrado para cargos directivos o de responsabilidad en la Administración pública (y organismos públicos) por parte de quien ha desempeñado cargos políticos en los dos años inmediatamente anteriores. La inadecuación se hace extensiva igualmente a quienes han sido condenados por delitos contra la Administración.

La inadecuación de nombramientos trata de evitar así situaciones de posible confusión entre la política y la Administración, previendo un período de obligado distanciamiento para que la actividad de procedencia no enturbie o ponga en peligro la actividad administrativa sometida estrictamente a la Constitución y al resto del ordenamiento jurídico.

\section{ORDENAMIENTO ESPAÑOL}

\subsection{Jueces y magistrados del Poder Judicial}

Más allá de las disposiciones relativas al ejercicio de la función judicial en la Constitución y la LOPJ, el derecho positivo en España —en lo que a nosotros puede afectar - regula la independencia de los servidores públicos en la legislación de incompatibilidades y en materia de transparencia.

El principal escollo para entender comprometida la neutralidad ideológica y la independencia judicial del juez que ha sido alto cargo consiste en que el art. 127.1 CE se limita a impedir que los jueces y magistrados desempeñen otros cargos públicos mientras se hallen en activo. En desarrollo de este precepto, el art.

50 B. Ponti (2013), «La regolazione dell'accesso agli incarichi esterni da parte dei dipendenti dopo la legge 190/2012: evoluzione del sistema e problemi di applicazione agli enti territoriali», en Istituzioni del federalismo, págs. 409 y ss.; F. Merloni, «Nuovi strumenti di garanzia dell'imparzialità degli amministratori: l'inconferibilità e incompatibilità degli incarichi», en La legge anticorruzione, op. cit., págs. 196-209; D. Andracchio (2016), «Il divieto di 'pantouflage': una misura di prevenzione della corruzione nella pubblica amministrazione», en GiustAmm.it, 9, págs. 1-10.

51 E. Carloni, El sistema de la lucha ... op. cit., pág. 94. 
389.2 y 3 LOPJ declara incompatible el ejercicio de la función judicial con todo cargo de elección popular o designación política.

Como puede apreciarse, el derecho especial que afecta al estatuto de jueces y magistrados no resuelve la situación del juez que, después de haber ostentado un cargo político con su consiguiente carga ideológica, regresa a la carrera judicial y debe ejercer su actividad totalmente al margen de cualquier condicionamiento. La situación que analizamos no entra en el ámbito de aplicación ni de la Ley 53/1984 ni de la Ley 19/2013.

En España el Consejo General del Poder Judicial aprobó un Código Ético para la Carrera Judicial en sesión de 16 de diciembre de 2016. Este documento trae causa del documento sobre Deontología Judicial (Informe 2009-2010) aprobado por el Grupo de Trabajo de la Red Europea de Consejos de Justicia, que —en lo que a nosotros interesa - reconoce en su introducción que el papel del juez ha evolucionado y que «nuestras sociedades reclaman una mayor transparencia en el funcionamiento de las instituciones públicas».

Merece destacar sobre manera que, en materia de imparcialidad, este documento señala expresamente que «el juez deberá tomar conciencia de sus eventuales prejuicios», señalando como nota a pie de página que «la imparcialidad subjetiva está vinculada a la personalidad del individuo».

No en vano los principios de ética judicial del órgano español de gobierno de los jueces y magistrados se articulan en torno a la independencia, la imparcialidad y la integridad. Curiosamente no mencionan la neutralidad ideológica, si bien de cada uno de los mencionados principios sí se infieren conductas y modos de comportamiento que inciden en esta última. Así, en materia de independencia, el punto 2 entiende que:

El juez y la jueza deben situarse en una disposición de ánimo que, al margen de sus propias convicciones ideológicas y de sus sentimientos personales, excluya de sus decisiones cualquier interferencia ajena a su valoración de la totalidad de la prueba practicada, a la actuación de las partes en el proceso, de acuerdo con las reglas del procedimiento, y a su entendimiento de las normas jurídicas que haya de aplicar.

En su punto 6 obliga al juez a resistir todo intento directo o indirecto de terceros ajenos al proceso que tienda a influir en sus decisiones. $Y$ en el punto 9 que han de comportarse y ejercer sus derechos en toda actividad en la que sean reconocibles como tales de forma que no comprometan o perjudiquen la percepción que, en un Estado democrático y de derecho, tiene la sociedad sobre la independencia del Poder Judicial.

Más estrecha con la neutralidad ideológica es la imparcialidad, de manera que el principio 11 entiende que esta última «opera internamente respecto del mismo juzgador, a quien exige que, antes de decidir un caso, identifique y trate de superar cualquier prejuicio o predisposición que pueda poner en peligro la rectitud de la decisión». 
Por último, y en lo que a la integridad se refiere, merece destacar que el principio 31 se refiere a la libertad de expresión del juez, que debe acompañarse de prudencia y moderación con el fin de preservar su independencia y apariencia de imparcialidad, y mantener la confianza social en el sistema judicial y en los órganos jurisdiccionales.

\subsection{Magistrados del Tribunal Constitucional}

Un asunto en Espańa que no puede dejar de analizarse es la neutralidad ideológica de los magistrados del Tribunal Constitucional, especialmente a raíz de la recusación formulada por la comunidad autónoma de Cataluña contra el presidente de ese órgano constitucional, Sr. Pérez de los Cobos, cuando se hizo público que había militado en un partido político entre 2008 y 2011.

El Tribunal Constitucional, en el Auto del Pleno 180/2013, de 17 de septiembre de 2013 (rec. 3766/2006), distingue el régimen estatutario de jueces y magistrados integrantes del Poder Judicial, de los magistrados del Tribunal Constitucional, y para ello se remite al derecho positivo para hacer notar que la Constitución sí establece un régimen de prohibición de pertenencia a partidos políticos para los primeros, mientras que no lo hace para los segundos.

No se olvida el Auto de rebatir la previsión del art. 159.5 CE de que «en lo demás, los miembros del Tribunal Constitucional tendrán las incompatibilidades propias de los miembros del poder judicial», porque entiende que la pertenencia de aquellos a partidos políticos no es propiamente una incompatibilidad, sino una prohibición.

Para el Tribunal Constitucional existe una nota diferencial en relación con los miembros del Poder Judicial que el constituyente ha establecido conscientemente, a su entender, y que se corresponde con la especial naturaleza del Tribunal Constitucional, con la limitación temporal del mandato de sus miembros, con el carácter político de sus designaciones por los tres poderes del Estado y con el efecto de las propias resoluciones del tribunal, susceptibles de corregir las decisiones de esos tres poderes.

Entiende asimismo que la pertenencia a un partido político no afecta a su imparcialidad ni a su neutralidad, y fundamenta su razonamiento en derecho comparado $^{52}$ y en la jurisprudencia del TEDH, que declara que la afinidad ideo-

52 Esa nota diferencial del Tribunal Constitucional respecto del Poder Judicial resulta habitual en el derecho comparado. Así, en Alemania el art. 18.2 de la Ley del Tribunal Constitucional Federal, de 12 de marzo de 1951, dice en relación con sus magistrados que no se incurre en parcialidad por razón de la afiliación a un partido político. Y cabe destacar que el Tribunal Constitucional Federal, alemán ha afirmado que "la antigua pertenencia a un partido político no sólo no es incompatible con el desempeño de la función judicial, sino que cuando se trata de un Magistrado del Tribunal Constitucional, es precisamente esa experiencia política la que puede enriquecer la jurisprudencia del Tribunal» (Sentencia de 
lógica no constituye por sí sola causa de recusación ${ }^{53}$, sino que debe analizarse en cada caso si la independencia del magistrado se halla comprometida.

No obstante el parecer mayoritario expresado en el Auto, existen dos votos particulares discrepantes, para los que la neutralidad ideológica y la imparcialidad se hallan comprometidas en caso de militancia política del magistrado del Tribunal Constitucional y, en definitiva, lesionada la confianza social en el funcionamiento de la justicia constitucional.

El primero de ellos, del Excmo. Sr. Valdés Dal-Ré, justifica en la obra de Kelsen que el derecho positivo no haya prohibido expresamente la militancia política de los magistrados. Para este magistrado, el Tribunal Constitucional es un órgano de inequívoca naturaleza político-constitucional, derivando esta adje-

11 de agosto de 2009, 2 BvR 343/09). En Italia, la Ley de 11 de marzo de 1953 no prohíbe a los miembros de la Corte Constitucional, durante su mandato, la afiliación política, pero sí la realización de actividades relacionadas con asociaciones o partidos políticos. No obstante, en Italia no se permiten recusaciones de los miembros de la Corte Constitucional (art. 29 de la Norma Integradora de los procesos seguidos ante la Corte Constitucional de 7 de octubre de 2008) salvo en los procesos de enjuiciamiento penal de determinados altos cargos del Estado atribuidos a ese tribunal (art. 25 de la Ley 20 de 25 de enero de 1962). En Francia, el art. 2 del Decreto 59-1292 de 13 de noviembre de 1959, relativo a las obligaciones de los miembros del Consejo Constitucional, establece únicamente la prohibición de ocupar puestos de responsabilidad o de dirección en el seno de un partido o agrupación política. Igualmente en Portugal, la Ley 28/1982, de 15 de noviembre, de organización, funcionamiento y proceso del Tribunal Constitucional, impide el ejercicio de funciones en los órganos de los partidos, asociaciones políticas o fundaciones conexas (art. 28.1), pero no la afiliación a partidos o asociaciones políticas (art. 29.2); si bien esta afiliación queda suspendida ex lege durante el desempeño del cargo de magistrado (art. 28.2). Este fue el criterio implícito de las constituciones europeas inauguradoras de la jurisdicción constitucional concentrada —y, en España, el de la Ley de 14 de junio de 1933, reguladora del Tribunal de Garantías Constitucionales_-, que tampoco contemplaron la incompatibilidad entre la Magistratura constitucional y la mera afiliación a formaciones políticas.

53 El Tribunal Europeo de Derechos Humanos, en la STEDH de 22 junio 2004, caso Pabla Ky c. Finlandia, ha tenido la oportunidad de pronunciarse sobre la incidencia de la afiliación política en la imparcialidad de los miembros de tribunales. En la demanda que origina el mencionado proceso, fue alegada la falta de imparcialidad de uno de los jueces del Tribunal de Apelaciones de Helsinki, del que formaba parte en condición de especialista por razón de la materia, y que, simultáneamente, ostentaba la condición de miembro del Parlamento finlandés, situación permitida por el ordenamiento nacional. La demandante destacaba, además, la filiación política socialdemócrata del juez afectado, coincidente con la del presidente y la del primer ministro de la República en el momento de los hechos, señalando que los socialdemócratas tenían interés en la materia juzgada ( $§ 22$ y 24 y 33). Pues bien, para el Tribunal Europeo de Derechos Humanos, «aunque la demandante señala la filiación política de M. P., el Tribunal no encuentra ninguna indicación en este caso de que su pertenencia a un partido político concreto tuviera ninguna conexión o vínculo con ninguna de las partes en el procedimiento o con la sustancia del litigio presentado ante el Tribunal de Apelación» (§ 33), excluyendo así la vulneración del art. 6.1 del convenio (§ 35). 
tivación de su función y del objeto de sus resoluciones, así como de la fuente de su legitimación y el procedimiento de designación de sus miembros. No en vano, a su juicio el Tribunal Constitucional desempeña una función jurisdiccional con repercusión política; directa y netamente política, pues el derecho constitucional tiene contenido político en cuanto define los principios y valores configuradores de nuestro Estado plural y de nuestra convivencia, y precisa los límites de la acción y las relaciones entre los diversos poderes constituidos.

En consecuencia entiende que la confianza de la sociedad y de los poderes públicos que intervienen en los procedimientos de constitucionalidad no solo descansa en la garantía de independencia, sino también en la garantía de imparcialidad. Y que por ello la trascendencia política de los pronunciamientos del Tribunal Constitucional obliga a elevar el estándar cuando pueda existir sombra de parcialidad de los miembros de este tribunal.

Más crítico que el anterior es el voto particular del Excmo. Sr. Ortega Álvarez, para quien —si bien son legítimos los intereses de los agentes políticos en lograr una interpretación de la Constitución acorde con su programa políticola conexión de un magistrado con estos intereses a través de su militancia política configura una duda más que razonable sobre la imparcialidad objetiva de dicho magistrado en este tipo de asuntos.

Para este catedrático de Derecho Administrativo, un Tribunal compuesto por militantes estaría siempre bajo la sospecha de ser la trasposición de posiciones políticas, o bien, debido al no cumplimiento de una parte importante de sus miembros de la regla de la imparcialidad objetiva, no podría adoptar una decisión por falta de quorum.

El voto particular cita el Auto del Tribunal Constitucional 26/2007, de 5 de febrero, que - a raíz del recurso de inconstitucionalidad contra el Estatuto de Autonomía de Cataluña - se plantea sobre la recusación de un Magistrado (Excmo. Sr. Pérez Tremps) porque había redactado un dictamen para el Instituto de Estudios Autonómicos de la Comunidad Autónoma de Cataluña, que había servido de base para remitir al Parlamento propuestas normativas.

Por mayoría de votos el tribunal acordó la recusación, si bien se formularon cinco votos particulares, cuatro discrepantes y uno concurrente, lo cual da idea de la dificultad y complejidad del asunto que analizamos.

\section{LA DIFÍCIL INDEPENDENCIA DEL JUEZ QUE HA SIDO ALTO CARGO O PARLAMENTARIO}

De acuerdo con este planteamiento, a la luz del derecho positivo y de la interpretación jurisprudencial sobre la idea que las constituciones italiana y española tienen del juez, debemos admitir que el alto cargo o parlamentario que reingresa a la carrera judicial tiene una especial dificultad para el ejercicio de la función judicial. 
Podría decirse que esta supuesta falta de neutralidad resulta igualmente predicable a un funcionario de la Administración General que reingresa al servicio activo después de una situación administrativa de servicios especiales por ocupar algunos de los puestos enumerados en el art. 87 EBEP. Es más, en un contexto de creciente politización de la Administración, hasta puede dudarse de la neutralidad del funcionario que ha ocupado un puesto de libre designación. En los últimos años la opinión pública ve en la libre designación una sombra de nombramiento política cuando la libre designación conceptualmente no guarda relación alguna con la política; por el contrario, la libre designación consiste en una forma de provisión de puestos de trabajo que se limita a la apreciación discrecional por el órgano competente de la idoneidad de los candidatos en relación con los requisitos exigidos para el desempeño del puesto (art. 80 EBEP).

Sin embargo, y a pesar de los elementos comunes, en el juez esta dificultad es mayor por dos motivos: el primero porque, a diferencia de un funcionario, el juez ostenta un poder del Estado, de manera que su capacidad de influir en la vida de las personas (cualquier decisión judicial, incluida la privación de libertad) es infinitamente mayor que la de aquel. No se olvide por otra parte que los actos administrativos en los que pueda haber influido el funcionario que ha sido política, son objeto de revisión judicial, de manera que en última instancia la eventual falta de neutralidad del funcionario será corregida por el juez, sobre quien no puede existir duda alguna en cuanto a su independencia, imparcialidad y neutralidad ideológica.

En segundo lugar, porque - si bien existe y debe existir una confianza social en la Administración pública, que también es un poder del Estado- resulta más delicada la confianza social en la justicia. La Administración pública es la heredera del principio monárquico, que manera que — si bien se halla vinculada a la Constitución y al resto del ordenamiento jurídico por aplicación del principio de legalidad - no es menos cierto que en la relación jurídico-administrativa constituye una de las dos partes, por oposición al administrado. Por ello la confianza social es mayor en la justicia que en la Administración; el ciudadano ve al juez independiente, y en cambio ve al funcionario dependiente de la Administración.

En consecuencia, el juez que ha desempeñado puestos políticos se encuentra con un estigma notable, que afecta sobremanera a la confianza que la sociedad tiene en él. Posiblemente su independencia e imparcialidad no resulten afectadas, $y$ hasta puede que haga un esfuerzo en mantener su neutralidad ideológica, pero no es menos cierto que los ciudadanos verán en él —si no a un político antes que a un juez- como mínimo a un juez politizado, y en todo caso explicarán sus decisiones desde la vertiente ideológica, lo cual es nefasto para la justicia.

En el plano concreto, el juez no siempre conocerá de asuntos en los que intervenga la política, si bien durante el resto de su carrera a ese juez le perseguirá la sombra de su paso por la política.

No se olvide que el régimen asociativo de jueces y magistrados ya incide en la neutralidad ideológica y no en vano —en función de la pertenencia a una aso- 
ciación u otra, cada una de ellas cercana a una opción ideológica determinadase habla en los medios de "el juez conservador" o de "el juez progresista ${ }^{54}$. Por razones obvias estas expresiones merman la doctrina de la separación de poderes y en particular la independencia judicial.

Como hemos visto, por la especial sensibilidad de su actividad, el juez no es un mero servidor público, sino que representa un poder del Estado, de ahí que sobre el mismo se exija una manera de actuar -incluso fuera del ejercicio de la función jurisdiccional- que no puede comprometer los requisitos de independencia y neutralidad que se le exigen.

El principal escollo es que el derecho positivo se limita a impedir el ejercicio de la función judicial y la ocupación de cargos políticos al mismo tiempo, sin prever que la sucesión de estas actividades igualmente compromete la independencia y la neutralidad.

No se olvide que el juez que pasa a ocupar un escańo parlamentario o un cargo ejecutivo no deja de ser juez, sino que se limita a cambiar de situación administrativa: pasa del servicio activo a los servicios especiales, de manera que — mientras se dedica a la política - se le reconoce su condición de juez, se le reserva su puesto de trabajo y se le abonan trienios en concepto de antigüedad. En consecuencia, no existe una desconexión total de la judicatura cuando se ejerce una actividad política.

Por de pronto debe admitirse un distinto tratamiento que el derecho positivo otorga a los militares y a los jueces, aun cuando ambos colectivos de servidores públicos se encuentran sometidos por igual al principio de neutralidad ideológica.

En efecto, la neutralidad política y sindical de los militares es absoluta y no admite matices: «[...] no podrá fundar ni afiliarse a partidos políticos y mantendrá una estricta neutralidad pública en relación con la actuación de los partidos políticos» (art. 7 de la Ley Orgánica 9/2011, de 27 de julio, de derechos y deberes de los miembros de las Fuerzas Armadas). Solo el militar retirado puede desempeñar actividades políticas y sindicales (disposición adicional primera de la Ley Orgánica 9/2011).

Para los militares integra el tipo disciplinario de falta grave organizar o participar activamente en reuniones o manifestaciones de carácter político o sindical (art. 7.34 de la Ley Orgánica 8/2014, de 4 de diciembre, de Régimen Disciplinario de las Fuerzas Armadas), que, en caso de reiteración, constituye falta muy grave (art. 8.13). Y la sanción por falta muy grave puede implicar la separación del servicio y la resolución de compromiso (art. 11.3).

A mayor abundamiento otro gran problema que aflora en este punto consiste en la dificultad por controlar la independencia y neutralidad del juez. La función de control que opera el ordenamiento jurídico en cualquier orden se

54 J. E. Soriano García se refiere a esta cuestión como «el problema de la sumisión asociativa judicial». El poder, la Administración... op. cit., págs. 59 y ss. 
proyecta sobre un dato visible y objetivo. No en vano hemos hecho referencia a la independencia judicial respecto de injerencias externas de otros poderes.

Sin embargo, aquí planteamos la independencia del juez respecto de elementos internos suyos, de condicionantes particulares fruto de su experiencia, de su actividad política anterior al reingreso a la carrera judicial. Y debemos admitir la especial dificultad en verificar su adscripción exclusivamente al ordenamiento jurídico, máxime si se tiene en cuenta que la junción de juzgar es estrictamente personal e intelectual ${ }^{55}$. En este sentido, la LOPJ diseña un régimen de incompatibilidades y prohibiciones que son fácilmente de analizar a partir de datos objetivos. En cambio, los condicionantes que el juez pueda tener son tremendamente subjetivos y escapan a cualquier control.

En efecto, no está de más recordar en este punto, al decir de Nieto, que la dependencia verdaderamente importante no es la externa (posibilidad de influir en la decisión judicial por un comentario o sugerencia del poder político), sino cuando el juez pueda tener su decisión predeterminada en función de su opción ideológica:

En la actualidad esta es la variante más generalizada y su habitualidad es la nota más característica de los tiempos que corren. La dependencia no se refiere ya, por lo común, a la sumisión a la hora de tramitar (o no tramitar) ni de decidir (lo que podríamos llamar dependencia reaccional u obediencia a unas instrucciones concretas), si no a la identificación previa y global del juez con los objetivos e intereses del poder. Con la consecuencia de que aquí no hacen falta instrucciones porque el juez no las necesita: se adelanta a ellas. El juez conoce lo que quiere Mefistófeles y éste no necesita ejercer su influencia concreta porque aquél está dispuesto de antemano a tramitar y decidir a gusto de éste. Es la dependencia militante. El juez activo, no meramente reaccional ${ }^{56}$.

Por razones obvias no se puede generalizar esta actitud de ideología militante porque la inmensísima mayoría de jueces y magistrados —aunque tengan lógicamente su ideología — ni tan siquiera tienen asuntos en los que tengan la más mínima posibilidad de proyectarla. Piénsese, por ejemplo, en un juez de primera instancia, de instrucción o de lo social. En ese caso solo las causas de abstención y recusación (art. 219 LOPJ) son las que deben operar si alguna de las partes tiene una proyección política (es indiferente a estos efectos que sea coincidente o contraria a aquella en que haya militado el juez en su etapa política).

El juez de lo contencioso, en cambio, va a tener que revisar un acto administrativo dictado por una entidad de derecho público que sí tendrá connotaciones políticas, porque esa entidad estará gobernada por personas de un partido político

55 Para A. Nieto, «el decidirse a hacer justicia es, por tanto, una cuestión rigurosamente personal del juez», (2002) Balada de la Justicia y la Ley, Madrid: Trotta, págs. 247 y 248.

56 A. Nieto (2010), El malestar de los jueces y el modelo judicial, Madrid: Trotta, pág. 132. 
u otro, de manera que el fallo de la sentencia corre el riesgo de ser interpretado desde la política.

En consecuencia se aprecia una primera distinción entre órdenes jurisdiccionales, viendo que el contencioso resulta más sensible para el juez que ha sido alto cargo o parlamentario. Dicho de otra manera, no tanto la independencia ni la imparcialidad, pero sí la confianza social en el poder judicial se torna más vulnerable a la hora de revisar actos administrativos y no otro tipo de asuntos, porque en aquellos existe la política y en estos no.

Por último, no podemos dejar de mencionar, para el supuesto específico de magistrado del Tribunal Supremo, el art. 357 LOPJ, que determina la pérdida de la condición de tal en los casos de excedencia voluntaria, con la excepción del cuidado de hijos o de familiares ${ }^{57}$.

\section{RECOMENDACIONES DE LEGE FERENDA: HACIA UN CÓDIGO DE CONDUCTA DE JUECES Y MAGISTRADOS}

La descripción del régimen jurídico español e italiano de las prohibiciones e incompatibilidades de los miembros de la carrera judicial confirma la necesidad de una reforma, dirigida fundamentalmente a preservar la idea que la Constitución tiene del juez, un juez imparcial, independiente (hasta de sí mismo) y sobre el que la sociedad no tenga un atisbo de duda en su neutralidad.

La afectación a estos requisitos en el caso del juez que ha sido alto cargo o parlamentario sencillamente no está resuelta en el ordenamiento, ni mucho menos contemplada. Y ello reviste una importancia capital en un Estado de derecho porque la quiebra de la confianza de los ciudadanos en la judicatura puede desencadenar un regreso a métodos menos civilizados de la solución de controversias ${ }^{58}$.

Con carácter previo soy partidario de aplicar algún género de restricción a los jueces y magistrados que han ocupado cargos superiores en la Administración (ministro y secretario de Estado) o han sido parlamentarios, y en cambio no someter a limitación alguna al juez que ha ocupado puestos directivos de la Administración pública, en los que se ha primado un perfil técnico.

57 La Comisión Permanente del Consejo General del Poder Judicial, por cinco votos frente a tres, aplicó este fundamento jurídico a la actual ministra de Defensa del Gobierno de la Nación, que era magistrada de la Sala Tercera del Tribunal Supremo desde 2004, al serle concedida la excedencia voluntaria para ser diputada en Cortes por Madrid y posteriormente ministra. En fecha 19 de mayo de 2016 se resolvió la pérdida de la condición de magistrada del Tribunal Supremo y en fecha 26 de julio siguiente la Comisión permanente desestimó el recurso formulado por la Sra. Robles.

58 J. A. Climent Gallart (2018), «La jurisprudencia del TEDH sobre la libertad de expresión de los jueces», Rev. Boliv. de Derecho, págs. 527 y 528. 
La opción italiana de obligar al servidor público que ha ocupado puestos de responsabilidad política a pasar por un tiempo de enfriamiento de dos años personalmente no entiendo que sea aplicable al reingreso a la carrera judicial. Como tampoco entiendo aplicable la Ley española reguladora del ejercicio del alto cargo de la Administración General del Estado.

A mi modo de ver, creo pertinente reformar la LOPJ e incluir una incompatibilidad sucesiva de carácter temporal, que, para el caso del juez o magistrado que ocupe un puesto de responsabilidad política, durante un período de entre dos y cinco años no podrá tener destino en cualquier juzgado o tribunal del orden contencioso, sin que ello deba comportar compensación económica alguna porque la restricción es meramente de destino y no le impide el reingreso a la carrera judicial.

Una solución más drástica consistiría en impedir que el juez pueda reingresar por completo a la carrera judicial durante un tiempo, y deba dedicarse a cualquier ocupación profesional. Particularmente me parece una opción excesiva, aunque resulta comparable a la prohibición durante dos años de dedicarse al sector de actividad en el que se ha trabajado siendo alto cargo.

$\mathrm{Y}$ otra opción consiste en reforzar el régimen de la abstención y la recusación, permitiendo al juez el reingreso, si bien siendo especialmente riguroso en la necesidad de que se abstenga de todo proceso en el que exista un componente político.

Particularmente no me parece suficiente el Código Ético para la Carrera Judicial, toda vez que constituye una eficacia relativa a su independencia judicial y a su imparcialidad. No pretendo minusvalorar que al juez le resulta útil una "guía» jurídica que le otorgue seguridad respecto a su intervención en actos académicos, conferencias, artículos de prensa... Nadie discute, por ejemplo, que un juez no puede recibir un regalo; sin embargo, ¿puede recibir una medalla de un gobierno $^{59}$ ? ¿Acaso no le afecta a su independencia? ¿Puede participar en actos promovidos por entidades adscritas a partidos políticos? Todas estas cuestiones podrían aclararse negro sobre blanco en un documento confeccionado con participación de los propios jueces y magistrados, y dejarían de estar al albur de una jurisprudencia cambiante ${ }^{60}$.

Sin embargo, y en lo que afecta a la neutralidad ideológica, el Código de Conducta no deja de ser un elemento de difícil efectividad y control. En todo

59 El juez instructor del caso Palma Arna, que durante más de diez años y a lo largo de veintisiete piezas separadas se juzgó al expresidente de Baleares (Partido Popular) Jaime Matas, fue condecorado por la presidenta del Gobierno autonómico (Partido Socialista Obrero Espańol) con el Premio Ramón Llull en 2018.

60 J. E. Soriano García (2017), «De nuevo, el Poder, la Administración y los Jueces», en L. Parejo Alfonso y J. Vida Fernández (coords.), Los retos del Estado y la Administración en el siglo XXI: libro homenaje al profesor Tomás de la Quadra-Salcedo Fernández del Castillo. Valencia: Tirant lo Blanch, págs. 667 y ss. 
caso, aun subrayando la insuficiencia de este código, sugiero que se incorpore un principio relativo a la actividad política de los jueces.

En Estados Unidos, pese a la intervención del poder político en el nombramiento de determinados jueces, existe un Código de Conducta para los Jueces (Code of Conduct for United States Judges), cuyo canon 5 precisamente lleva por rúbrica «Un juez debería evitar la actividad política» (A Judge Should Refrain from Political Activity) con los siguientes mandatos:

A) Prohibiciones generales. Un juez no debe:

1) actuar como líder o ejercer cualquier cargo en una organización política;

2) hacer discursos para una organización política o un candidato, o respaldar públicamente u oponerse a un candidato para un cargo público; o

3) solicitar fondos para pagar una evaluación o hacer una contribución a una organización política o a un candidato, o asistir o comprar un boleto para una cena u otro evento patrocinado por una organización política o candidato.

B) Renunciar a la candidatura. Un juez debe renunciar a la función judicial si el juez se convierte en candidato en una elección primaria o general para cualquier cargo.

C) Otra actividad política. Un juez no debe participar en ninguna otra actividad política. Esta disposición no impide que un juez se involucre en las actividades descritas en el canon 4, que se refiere a actividades cívicas, de caridad, educativas...

En conclusión considero que esta experiencia del derecho comparado puede resultar provechosa en España, si bien adicionalmente debería reformarse la LOPJ al objeto de limitar temporalmente la actividad judicial de jueces y magistrados que han desempeñado labores políticas, en defensa de la independencia judicial, la imparcialidad y la confianza social en la justicia. 
